\title{
ATRIAL NATRIURETIC HORMONE SECRETION IN PATIENTS WITH RENAL FAILURE
}

\author{
Yoram Shenker, Friedrich K. Port, Richard D. Swartz, \\ Milton D. Gross, and Roger J. Grek in \\ Sections of Endocrinology and Metabolism, \\ Nephrology, and Nuclear Medicine \\ VA Medical Center and The University of Michigan \\ Ann Arbor, Michigan 48105 U.S.A.
}

(Received in final form July 23, 1987)

\section{Summary}

To study the effects of volume overload and renal failure on plasma levels of immunoreactive atrial natriuretic hormone (IR-ANH), we measured levels of this hormone in normal subjects, in patients with advanced chronic renal failure (CRF) with and without clinically evident volume overload, and in patients with end-stage renal disease (ESRD) treated with chronic hemodialys is. The levels were $13 \pm 2 \mathrm{pmol} / 1$ in normal volunteers, $77 \pm 24$ pmol/ 1 in patients with CRF without volume overload, and $219 \pm 50 \mathrm{pmo} / / 1$ in patients with CRF and clinically evident volume overload (analys is of variance, $p<0.001, a=0.05$ compared to normals). In patients with ESRO, the levels of IR-ANH were $145 \pm 46$ pmol/1 before dialysis and decreased to $87 \pm 31$ after dialys is $(p<0.025)$. No correlation was found between the decrease in IR-ANH levels and the decrease in weight during dialysis. A significant positive correlation was found between the IR-ANH levels and blood urea nitrogen in patients with CRF $(r=0.658, p<0.01)$.

Volume overload appears to be the most important stimulatory factor for ANH secretion in renal failure patients but other mechanisms, especially a decrease in metabolic clearance, may also contribute to elevated plasma levels. The increased secretion of ANH in patients with renal failure may be an important adaptive response to volume overload and hypertension.

Atrial natriuretic hormone (ANH) is a term for a group of peptides with potent natriuretic, diuretic and vasorelaxant activity in animals and humans (1-4). Recently, measurable levels of ANH have been found in rat and human plasma (5-11) and specific membrane receptors have been described in arterial smooth muscle, renal and adrenal cortical tissue $(12,13)$. Based on these data the hormonal role of this peptide seems to be assured and we will use the term ANH in this paper.

The mechan isms which regulate secretion of ANH are still largely unknown, but an increase in atrial pressure, probably by atrial stretch, is a potent stimulator of ANH release (7). Volume overload has been shown to enhance the ANH secretion in both animals (7) and humans $(10,14)$. 
To evaluate the effect of volume over load and renal failure on ANH secretion we measured the levels of immunoreactive ANH (IR-ANH) in normal volunteers, patients with advanced chronic renal failure (CRF), and patients with end-stage renal disease (ESRD) on maintenance hemodialysis.

\section{Methods}

\section{Subjects}

Thirty one normal volunteers (12 women and 19 men) aged 19-39 years (mean \pm SE $25 \pm 1$ ) had a single blood sample drawn in the recumbent position. Thirteen patients ( 4 women and 9 men) aged $23-73$ (mean $45 \pm 5$ ) on a chronic hemodialys is program were studied 3 days after their previous treatment. All had clinical evidence of volume overload. Subjects had all eaten 30 to 90 minutes prior to dialysis. One blood sample was drawn from the venous line before dialysis and another blood sample was drawn from the same line 10 minutes before the end of the dialysis. In nine of the 13 patients an additional blood sample was drawn from the arterial line 10 minutes before the end of the dialysis. In five of the dialysis patients, plasma volume was measured prior to and 10 minutes before the end of the dialysis using albumin iodinated with $131_{\text {I }}(15)$.

The cause of renal failure in the 13 patients with ESRD was glomerulonephritis in seven patients, chronic pyelonephritis in three patients, and interstitial nephritis, diabetic nephropathy and nephroscleros is in one patient each. One patient had undergone bilateral nephrectomy. The patients had been treated with chronic hemodialysis for 3 months to 11 years before the study (mean $4.0 \pm 1.2$ year, median 1.5 years). The dialyzers used included Cordis-Dow 135 SCE for 9 patients, and CA 110, CA 90, SCE 90 and Hospal 3000 for one patient each. Standard dialysate compositions of 136-140 mEq/ 1 sodium, 0-3 mEq/l potassium, 3.25-3.5 mEq/ 1 calcium, and 1-1.5 $\mathrm{mEq} / 1$ magnes $\mathrm{i}$ um were used.

Another group of 16 patients with CRF was also studied. All were males aged $37-86$ years (mean $61 \pm 3$ ) and none of them was treated with dialys is. Their blood urea nitrogen (BUN) levels were 47-124 mg/dl (mean $79 \pm 5$ ). Seven had diabetic nephropathy, three had nephrosclerosis, two had analgesic nephropathy, and one each had polycystic kidney disease, IgA nephropathy, obstruction and Henoch-Schonlein syndrome as the cause for their renal failure. Eight of the 16 patients had clear evidence of volume overload (prominent pedal edema). Patients with renal failure were on a wide variety of medications including diuretics (for the CRF group), other antihypertensive agents, calcium carbonate, phosphate binders and others.

The study was approved by the Human Studies Committee of the University of Michigan Hospitals.

\section{Ass ay methods}

Plasma IR-ANH levels were measured by radioimmunoassay (9). In brief, blood samples, drawn into EDTA tubes, were put on ice and plasma was separated with in 30 min of sampling. Plasma was extracted through $C_{18}$ Sep Pak

cartridges (Waters Associates, Milford, MA) and IR-ANH levels were measured by radioimmunoassay. The intra- and interassay variations were 8.6 and $14.2 \%$ respectively. Serial dilutions of plasma samples from renal failure patients were closely parallel with the standard curve (Fig. 1). 


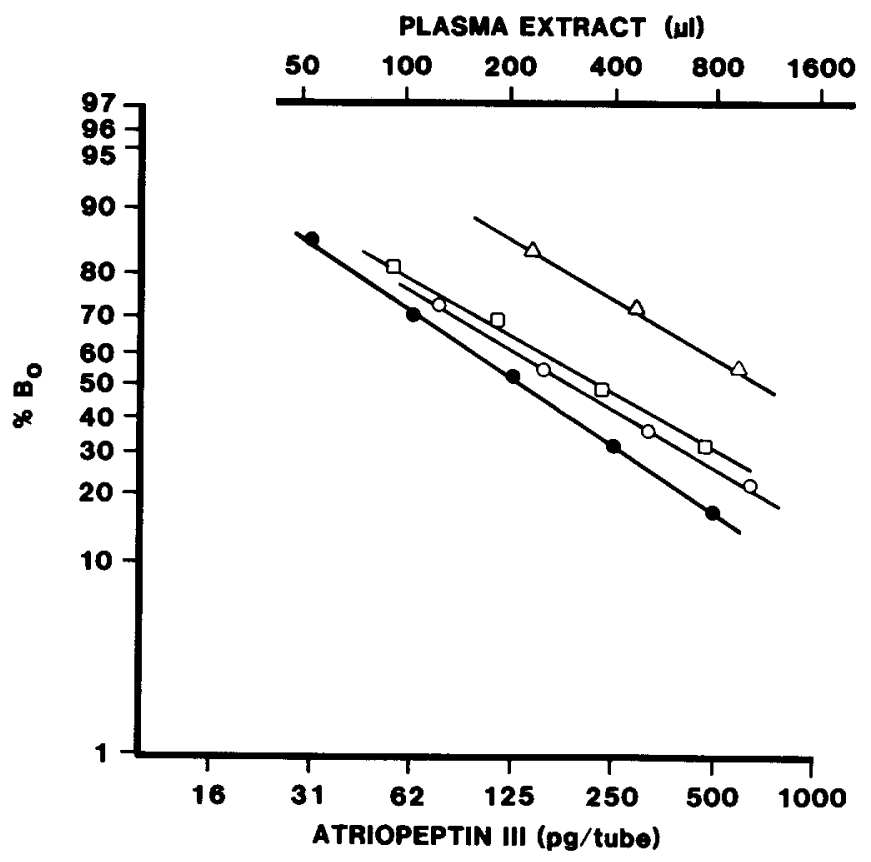

FIG. 1

Serial dilutions of plasma samples from patients with ESRO and CRF compared with the standard curve for IR-ANH us ing logit-log transformation. $\quad O \square-$ ESRD patients, $\triangle$-patients with CRF, - standard curve.

Statistical methods

The results are expressed as mean \pm standard error. Analys is of variance (ANOVA) with Newman-Keuls test $(\alpha=0.05)$, paired Student's $t$ test, and paired and unpaired Wilcoxon test (for data not normally distributed) with Bonferroni's protection were used. The CLINFO computer system of the University of Michigan Clinical Research Center was used for data storage and analysis.

\section{Results}

The distribution of IR-ANH levels in different groups of patients and volunteers is shown in Fig. 2. There was a significant variability between groups (ANOVA, $p<0.001$ ). Patients with CRF and volume overload had IR-ANH levels significantly higher than normals or patients with CRF without clinical evidence of volume overload (NKT, $\alpha=0.05$ ). The levels of IR-ANH before dialysis were significantly higher than those in normal volunteers (NKT, $\alpha=0.05)$. Patients with CRF without clinical evidence of volume overload had plasma IR-ANH levels which were not significantly higher than normal. 


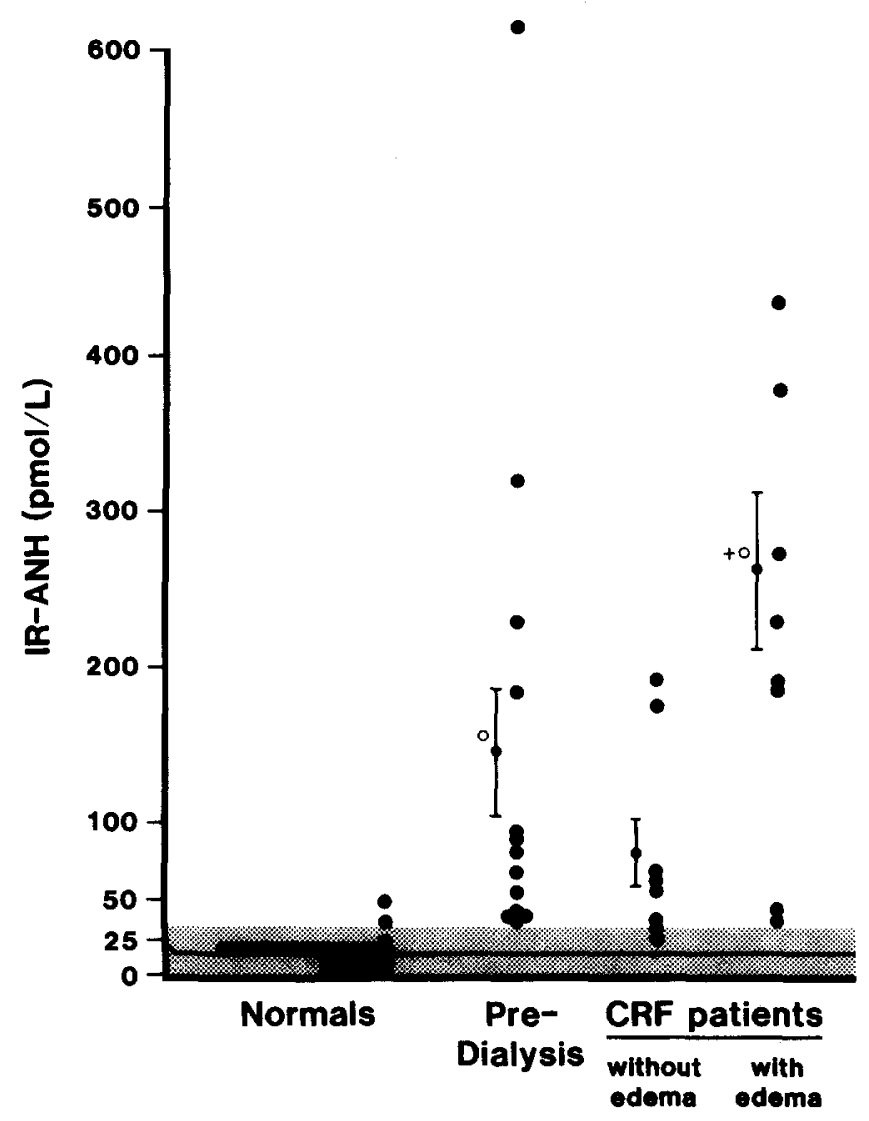

FIG. 2

Distribution of IR-ANH levels in patients with renal failure and normal volunteers. $p<0.001$, ANOVA; O significantly different than normals, + significantiy different than CRF patients without clinical evidence of volume overload. Shaded area represents mean \pm 2 S.D. for normal volunteers; mean \pm S.E. are shown for patients. 
Mean blood pressure, heart rate and weight before and after dialys is are shown in Table 1 . Six of the patients were hypertensive (mean B.P. > 107) before dialysis. Blood pressure returned to normal during dialys is in five of the six. There was a significant decrease in mean blood pressure and body weight during dialysis (paired t test, $p<0.01$ ). The decrease in heart rate was close to being statistically significant (paired t test, $p=0.058$ ).

Table 1.

Body weight, heart rate and mean blood pressure in ESRO patients before and after dialys is

$\begin{array}{lccc} & \text { Weight } & \text { Heart Rate } & \text { Mean B.P. } \\ \text { Pre-dialysis } & 64.5 \pm 2.5 & 85 \pm 3 & 104 \pm 5 \\ \text { Post-dialysis } & 62.2 \pm 2.6 * & 91 \pm 4 & 94 \pm 3 * \\ * p<0.01 \text {, paired Student's t test compared to pre-dialysis }\end{array}$

Plasma IR-ANH levels in ESRD patients before and after dialys is are shown in Fig. 3. There was no significant correlation of basal IR-ANH level with either age or blood pressure. The IR-ANH levels decreased significantly from $145 \pm 46 \mathrm{pmol} / 1$ before dialys is to $87 \pm 31 \mathrm{pmol} / 1$ after dialysis and both levels were significantly higher than those in normal volunteers (paired and unpaired Wilcoxon test with Bonferroni's protection $p<0.025)$. Nine ESRD patients showed a prominent decrease in IR-ANH levels after the dialysis, three had only minimal changes and in one patient the IR-ANH levels actually increased after the dialysis. This patient had the highest heart rate after the dialys is ( 126 beats per minute) and her mean blood pressure increased following the dialys is in contrast to the prominent decreases which occurred after dialysis in the other ESRD patients. There was no significant difference in IR-ANH levels between hypertensive and normotensive patients.

Nine patients had simultaneous arterial and venous line samples drawn just before the end of the dialysis. There was an $8 \%$ decrease in IR-ANH levels in blood from the venous line as compared to the arterial line (from $59 \pm 11$ to $54 \pm 11 \mathrm{pmol} / 1$ ). This decrease was statistically significant (paired $t$ test, $p<0.01$ ). The calculated diffusive clearance of IR-ANH by the dialyzer was $21 \mathrm{ml} / \mathrm{min}$ at an average blood flow rate of $246 \mathrm{ml} / \mathrm{min}$.

There was no correlation between the decrease in IR-ANH levels and the decrease in body weight during the dialys is in ESRO patients. There was also no correlation between the decrease in plasma volume and the decrease in IR-ANH (data not shown). 


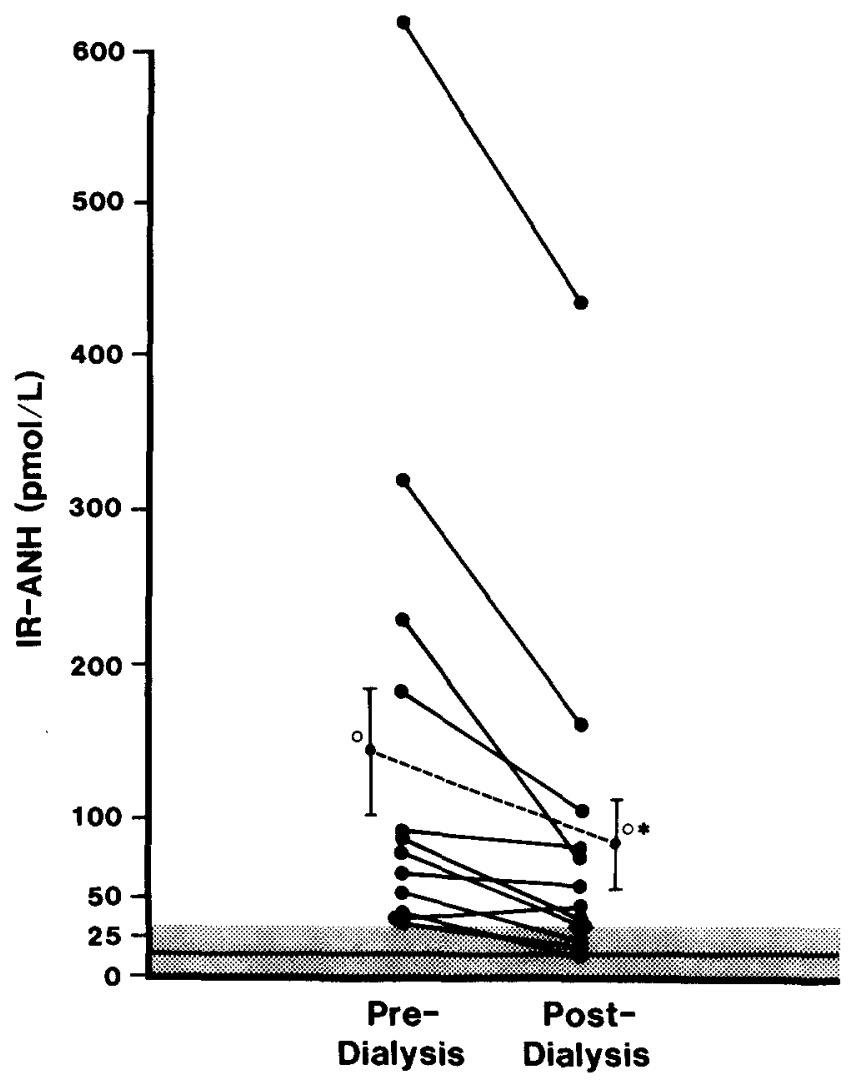

FIG. 3

Distribution of IR-ANH levels in ESRD patients before and after dialysis. $0-p<0.025$, wilcoxon test with Bonferroni's protection compared to normals. $*-p<0.025$, paired Wilcoxon test with Bonferroni's protection compared to pre-dialysis. 
In patients with CRF there was a signficant correlation between IR-ANH and BUN (1inear regression analysis, $r=0.658, p<0.01-$ Fig. 4 ). There was no significant correlation between IR-ANH levels and BUN levels in patients with ESRO.

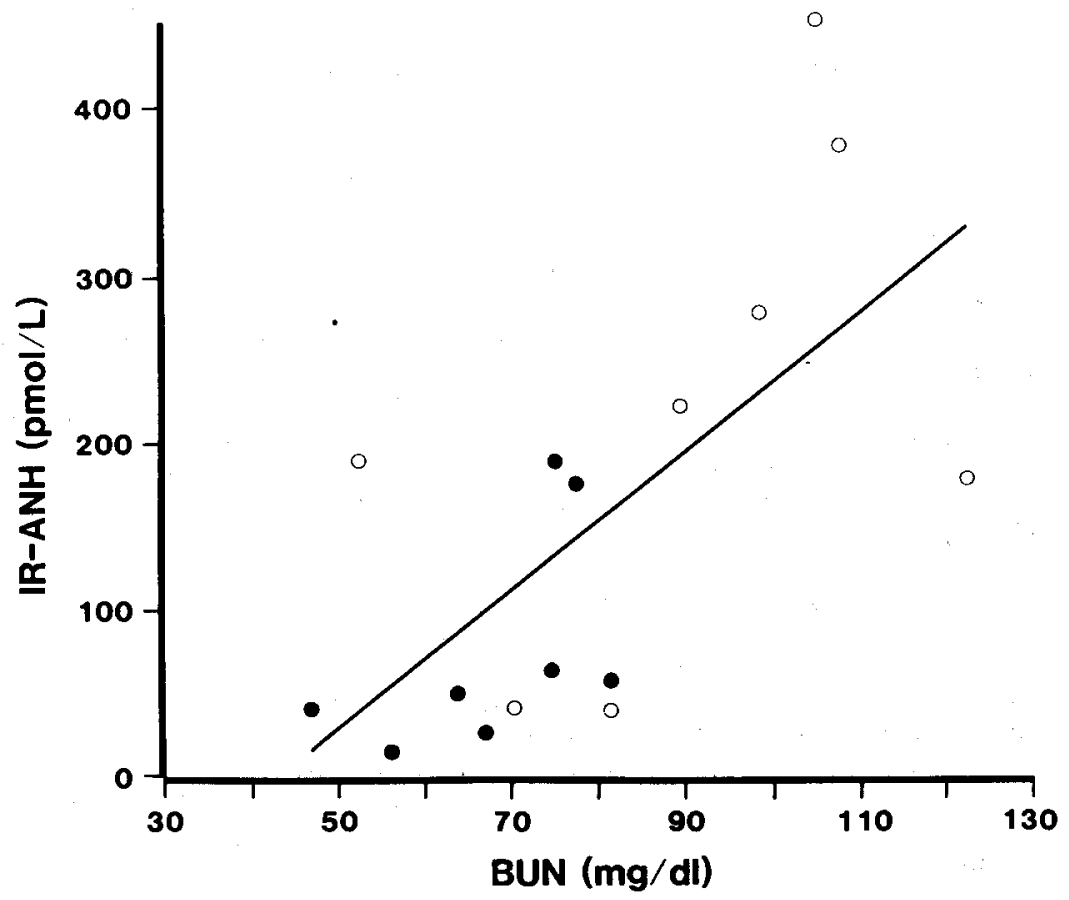

FIG. 4

IR-ANH levels as a function of BUN in patients with CRF. $r=0.658$ $p<0.01$, linear regression analysis. 0 - patients with edema, - patients without edema.

\section{Discussion}

This study shows that patients with renal failure have elevated levels of IR-ANH. This applies to patients with ESRD on chronic hemodialysis as well as to patients with CRF and volume overload. This latter group had IR-ANH levels which were the highest of all our study groups $(219 \pm 50 \mathrm{pmol} / 1)$. Patients with CRF without volume over load had plasma IR-ANH levels of $77 \pm 24 \mathrm{pmol} / 1$ and six of eight had plasma levels higher than the mean \pm 2 SD for normal volunteers (higher than 31 pmol/1). This elevation was not significant when compared to normal volunteers $(13 \pm 2$ pmol/l). BUN levels higher than $70 \mathrm{mg} / \mathrm{dl}$ were associated with elevated levels of IR-ANH. In a pediatric study, Rascher et al. (16) reported that children with CRF who had no evidence of volume expansion had IR-ANH levels slightly but not significantly higher than normal. Two of six children with CRF had IR-ANH levels which were higher than normal but their renal function was not reported. We would postulate that volume overload may be undetected in patients with CRF and yet be the stimulus for increased secretion of ANH. 
It has recently been shown both in vivo and in vitro that approximately $80 \%$ of ANH bioactivity is removed by the kidney (17). Advanced renal disease may well be associated with a decrease in renal clearance, which together with stimulation of ANH secretion by volume overload is likely to be responsible for high IR-ANH levels. In this regard, the effects of renal failue on IR-ANH metabolism appear to be similar to those on the metabolism of the C-terminal portion of parathyroid hormone (18). In patients with CRF the contribution of decreased renal clearance may be important as suggested by the significant correlation between IR-ANH levels and BUN in these patients (Fig. 4).

The patients with ESRO studied had clinical evidence of volume overload and hemodialysis caused a significant decrease in their volume overload as documented by changes in blood pressure, heart rate and body weight (Table 1). This decrease in volume over load is probably the major cause for the significant decrease in IR-ANH levels during dialys is ( $F i g .3$ ). The very high levels of IR-ANH in patients with CRF and clinically evident volume over load as well as the decrease in IR-ANH levels caused by the dialys is suggest that volume over load is the most important factor in regulation of ANH secretion in these patients. This is compatible with the results of the study in pediatric renal patients (16) and also with the documented effect of acute volume over load in animals (17) and man $(10,11)$. Similar mechanisms probably cause increased levels of IR-ANH in patients and animals with congestive heart failure $(9,11,19)$.

An al ternative explanation for the decrease in IR-ANH levels after the dialys is would be elimination of ANH from plasma by the dialyzer, either through filtration or degradation. The modest losses of circulating peptide during passage through the dialyzer are compatible with the present understanding of ultrafiltration of peptides by the dialys is membrane (20). On the other $h$ and a clearance of $21 \mathrm{ml} / \mathrm{min}$ cannot be solely responsible for the observed decrease in IR-ANH of more than $30 \%$ during dialysis. Removal of $8 \%$ of ANH by the dialyzer is negligible when compared to the reported $50 \%-80 \%$ of removal of ANH in a single pass through the peripheral circulation $(17,21)$.

Another mechanism which could contribute to a decrease in IR-ANH levels following hemodialysis is dialysis related vasodilatation. This vasodilatation is explained by effects of acetate (22) and/or by increased inter leuk in-1 production $(23,24)$. Decreased atrial pressure following this vasodilatation could cause a further decrease in ANH secretion.

Volume overload is most probably not the only mechanism involved in the regulation of ANH secretion as suggested by the lack of correlation between the decrease in IR-ANH levels and the body weight loss during the dialysis. Our results in this regard are not in disagreement with those of Rascher et al. (16) al though our interpretation of the data is different. In both studies there is no correlation between changes in body weight and decrease in IR-ANH levels during dialys is. Other factors involved in regulation of ANH secretion may include stimulation by vasopressors such as angiotens in II or vasopressin, changes in sympathetic tone or presence of immunoreactive but biologically inactive metabolites.

In regard to possible vasopress in or angiotens in II mediated stimulation of ANH secretion, Katsube et al. (25) were able to show prominent increases in IR-ANH levels following administration of pharmacological doses of different pressor substances in rats. The changes in IR-ANH were closely correlated with changes in right atrial pressure. Nothing is known at the present about 
the effects of physiologic doses of vasopressors on ANH secretion. If these doses are indeed stimulatory we could postulate that they may contribute to high levels of IR-ANH in some renal failure patients. Further increases in vasopressor levels after the dialys is could blunt the decrease in IR-ANH caused by decrease in volume overload.

Increased sympathetic tone after the dialysis, implied by tachycardia and increased blood pressure, could be responsible for the increase in IR-ANH levels in one of our ESRD patients. Our preliminary data suggest that low dose infusion of epinephrine can cause a significant increase in IR-ANH levels (26). This effect is largely blocked by B-blocking agents (unpublished observation).

It is possible that renal disease may cause the accumulation of biologically inactive fragments of ANH which are measured by the immunoassay. To date, the only reported circulating form of ANH in human plasma is 28-amino-acid ANH (27).

The physiologic significance of elevated IR-ANH levels in renal failure patients remains to be determined. In many of our patients the levels were high enough to cause a diuretic and natriuretic effect as documented in normal volunteers (11). The concentrations needed for a vasorelaxant effect are unknown. In rats with CRF, infusion of ANH causes a significant increase in glomerular filtration rate and decrease in blood pressure (28). The increased secretion of ANH in patients with renal failure may be an important adaptive response to volume retention and hypertension associated with renal disease.

\section{Acknowledgements}

The authors are indebted to Richard S. Sider for technical assistance and to the nurses of the University of Michigan Dialysis Unit and the Washtenaw Regional Dialys is Center. This work was supported in part by Grant HL 18575 of the NHLBI and by the Research Service of the Veterans Administration.

\section{References}

1. A.J. deBOLD, M.B. BORENSTEIN, A.T. VERESS and M. SONNENBERG, Life Scj. 28, 89, (1981).

2. A.A. SEYMOUR, E.H. BLAINE, E.R. MAZACK, S.G. SMITH, I.I. STABILITO, A.B. HALEY, M.A. NAPIER, M.A. WHINNERY and R.F. NUTT, Life Sci. 36, 33 (1985).

3. M.G. CURR IE, D.M. GELLER, B.R. COLE, J.G. BOYLAN, W. YUSHENG,

S.W. HOLMBERG and P. NEEOLEMAN, Science (Wash. DC) 221, 71 (1983).

4. A.M. RICHAROS, M.W.I. WEBSTER, H. IKRAM, M.G. NICHOLLS, T.G. YANOLE and E.A. ESPINER, Lancet 1,545 (1985).

5. J. GUTKOWSKA, K. HORKY, G. THIBAULT, P. JANUSZEWICZ, M. CANTIN and J. GENEST, Biochem. Biophys. Res. Cormun. 125, 315 (1984).

6. I. TANAKA, K.S. MISONO and T. INAGAMI, Biochem. Biophys. Res. Commun. $124,663(1984)$.

7. R.E. LANG, H. THOLKEN, D. GANTEN, F.C. LUFT, M. RUSKOAHO and T. UNGER, Nature (Lond.) 314, 264 (1985).

8. J. GUTKOWSKA, M. BOURASSA, D. ROY, G. THIBAULT, R. GARCIA, M. CANTIN and J. GENEST, Biochem. Biophys. Res. Commun. 128, 1350 (1985).

9. Y. SHENKER, R.S. SIDER, E.A. OSTAFIN and R.J. GREKIN, J. Clin. Invest. 76, 1684 (1985).

10. T. YAMAJI, M. ISHIBASHI and F. TAKAKU, J. Clin. Invest. 76, 1705 (1985).

11. I. TIKKANEN, F. FYHRQUIST, K. METSARINNE and R. LEIDENIUS, Lancet 2,66 (1985). 
12. M.A. NAPIER, R.L. VANDLEN, G. ALBERS-SCHONBERG, R.F. NUTT, S. BRADY, T. LYLE, R. WINQUIST, E.P. FAISON, L.A. HEINEL and E.H. BLAINE, Proc. Nat1. Acad. Sci. USA 81, 5946 (1984).

13. A. DelEAN, J. GUTKOWSKA, M. MCNICOLL, P.W. SCHILlER, M. CANTIN and J. GENEST, Life Sci. 35, 2311 (1984).

14. G.A. SAGNELLA, N.D. MARKANDU, A.C. SHORE and G.A. MacGREgOR, Lancet 2 , 1208 (1985).

15. J.C. SISSON, CRC Manual of Nuclear Medicine Procedures, p. 132, CRC Press, West Palm Beach (1978).

16. W. RASCHER, T. TULASSAY and R.E. LANG, Lancet 2, 303 (1985).

17. E.0. WESELCOUCH, W.R. HUMPHREY and J.W. AIKEN, Am. J. Physiol. (Regulatory Integrative Comp Physiol) 249, R595 (1985).

18. T. MAACK, V. JOHNSON, S.T. KAU, J. FIGUEIREDO and D. SIGULEM, Kidney Int. 16,251 (1979).

19. J.R. LEDSOME, N. WILSON, C.A. COURNEYA and A.J. RANKIN, Can. J. Physiol. Pharmacol. 63, 739 (1985).

20. Z. WICHMAN, W. PAJOAK, O. SMOLENSKI and Y. KOPEC, Kidney Int. 28, 518 (1985).

21. T.G. YANOLE, I. CROZIER, E.A. ESPINER, H. IKRAM and M.G. NICHOLLS, Hypertens ion 7, 838 (Abstract \# 8) (1985).

22. V. GRAEFE, J. MILUTINOVICH, W.C. FOLLETE, J.E. VIZZO, A.L. BABB and B.H. SCRIBNER, Ann. Intern. Med. 88, 332 (1978).

23. L.W. HENDERSON, K.M. KOCH, C.A. OINARELLO and S. SHALDON, Blood Purification 1,3 (1983).

24. C.A. OINARELLLo, Blood Purification 1, 197 (1983).

25. N. KATSUBE, D. SCHWARTZ and P. NEEDLEMAN, Biochem. Biophys. Res. Commun. 133,937 (1985).

26. J.A. SANF IELD, Y. SHENKER, R.J. GREKIN and S.G. ROSEN, Clin. Res. 33, 828A (1985).

27. R.M. ARENDT, E. STANGL, J. ZAHRINGER, D.C. LIEBISCH and A. HERZ, Fed. Eur. Biochem. Soc. 184, 57 (1985).

28. B.R. COLE, M.A. KUHNLINE and P. NEEDLEMAN, J. Clin. Invest. 76,2413 (1985). 